\title{
Temporal frames of reference in Persian speakers language based on conceptual metaphors theory
}

\author{
1. Department of General Linguistics, Abadan Branch, Islamic Azad University, Abadan, Iran \\ 2. Associate Professor of Linguistics, Payame Noor University of Iran, Iran \\ 3. Assistant Professor of TEFL Department, Farhangian University of Ahvaz, Ahvaz, Iran
}

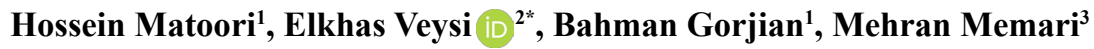

Recieved: 23 May. 2019

Revised: 23 Nov. 2019

Accepted: 16 Jan. 2020

Keywords

Temporal frames of reference

Persian

Mapping

Conceptual metaphors

Corresponding author

Elkhas Veysi, Associate Professor of Linguistics, Faculty of Humanities, Payame Nour University of Iran, Pardis Blvd, Ahvaz, Iran

Email: Elkhas@yahoo.com

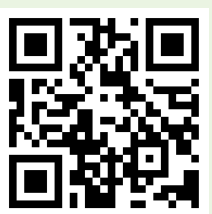

\section{Abstract}

Introduction: The present study aimed to examine the spatial-temporal mapping in Persian based on Lakoff and Johnson's conceptual metaphors theory to find the temporal frame reference its adoption sources. The metaphor of "time as space" is based on the hypothesis that we adopt an abstract concept such as time from an objective concept such as space and conceptualize it in our minds and languages.

Methods: The required data were analyzed by designing five experimental linguistic and non-linguistic experiments to achieve the research objectives. Experiments include temporal word arrangement, the arrangement of temporal stickers/tokens, and language elicitation with Wednesday meeting, picture arrangement, and co-speech gesture. One hundred fifty-five male and female students aged 18 to 54 from Islamic Azad University of Khorramshahr Branch and Abadan University of Medical Sciences participated in these experimental experiments.

Results: Samples' percentage and frequency of occurrence illustrated that lateral axis from right to left adopted from Persian writing direction; sagittal axis back to front adopted from walking direction, looking direction, linguistic metaphors; lateral axis from left to right adopted from mathematics writing direction are the main sources of adoption of abstract temporal concepts in Persian.

Conclusion: This research implied that the adopted frame of reference and the sagittal or lateral axes are strongly influenced by the type of task, pattern and design of the experiment, the given concepts, language and linguistic metaphors, and cultural artifacts.

Citation: Matoori H, Veysi E, Gorjian B, Memari M. Temporal frames of reference in Persian speakers language based on conceptual metaphors theory. Advances in Cognitive Sciences. 2020;22(1):102-115. 


\title{
جار حوب ارجاعى زمان در تويشوران زبان فارسى از منظر استعارههاى مفهومى
}

\author{
حسين مطورى'، الخاص ويسى "ID ، بهـمن ترجيان'، مهران معمارى"
}

\author{
I. كروه زبانشناسى همَانى، واحد آبادان، دانشكاه آزاد اسلامى، آبادان، ايران

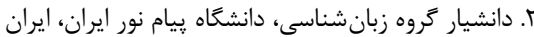

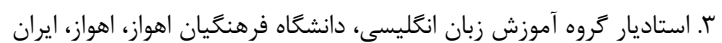

\begin{abstract}
בris
مقدمه: يزوهش حاضر نعاشت فضا-زمان را در زبان فارسى از منظر استعارههاى مفهومى Lakoff و Johnson مورد بررسى قرار داد تا حارجوب ارجاعى زمان و منابع اقتباس آن را دريابد. استعارة لزمان به مثابه فضاه بر اين فرضيه استوار است كه ما مفهوم انتزاعى جون زمان را از مفهوم عينى جون فضا الكوبردارى مى كنيم و آن را در ذهن و زبان خود مفهومسازى مىنماييم. روش كار: براى دستيابى به اهداف تحقيق، داده مورد نياز از طريق طراحى ه آزمايش زبانى و غيرزبانى به روش تجربى مورد بررسى قرار كرفت. آزمايشها عبارتند بودند از: آزمايش كتبى آرايش وازَّان زبانى، آزمايش حينش مهرههاى حاوى وازَٔان زمانى، آزمايش زبانشناختى جمله، آزمايش غير زبانى با عكس، و آزمايش ايما و اشارات كلامى. در اين

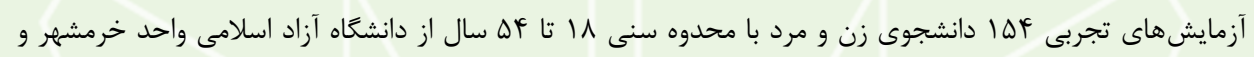
دانشعاه علوم يزشكى آبادان شركت نمودند. يافته ها: درصد و ميانگين بسامد وقوع نمونههاى مورد نظر جستار حاضر نشان داد كه محورهاى افقى جانبى راست به جֶٍ بركرفته از جهت نوشتارى زبان فارسى؛ محور افقى سهمى عقب به جلو بركرفته از جهت راه رفتن، استعارههاى زبانى، و جهت نكاه؛ و محور افقى جانبى جٍٍ به راست بركرفته از جهت نوشتارى اعداد و رياضيات مهمترين منابع اقتباسى مفاهيم انتزاعى زمان در زبان فارسى قلمداد مى كردند. نتيجه كَيرى: جار جوب ارجاعى اتخاذ شده و نوع محورهاى سهمى و جانبى بسيار تحت تاثير، نوع آزمايش، الكو و طراحى آزمايش، مفهوم مورد آزمايش، زبان و استعارههاى زبانى، و صنايع فرهنكى مى باشند.
\end{abstract}

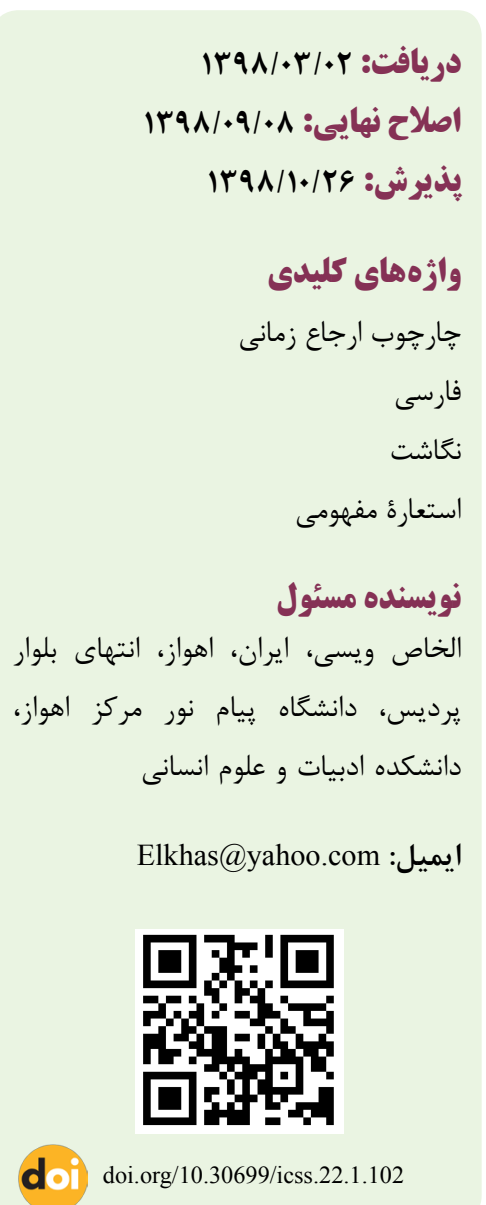

مقلدمه

نوشتارى (Writing direction)، جهت راه رفتن و نگاه (Walking)، (looking direction )، استعارههاى زبانى (Linguistic metaphors)،

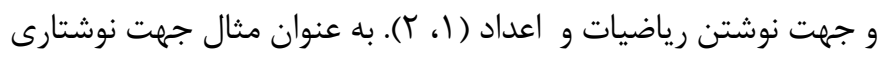
انكَليسى (جٍ به راست) به عنوان يك منشا استعارى مىتواند باعث

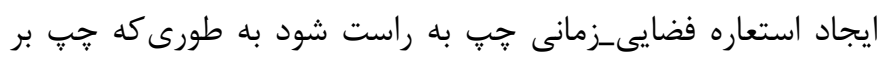

استعارة مفهومى "زمان به مثابئ فضاه (Time is like space) بر اين

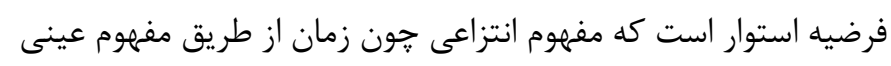

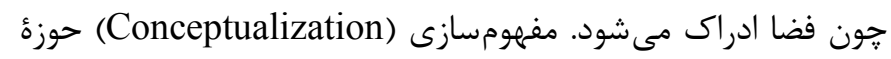
زمان بركرفته از حوزء فضا مى باشد. برخى منابع احتمالى اقتباس كه

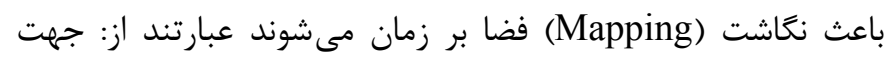


همسو با جهت راه رفتن و كذشته را به سمت يشت سر ناهمسو با جهت راه رفتن نشان دهند. يا به عنوان مثال اخر يك انغليسى زبان

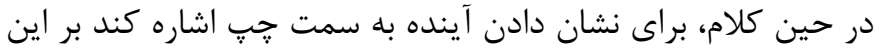
فرض دلالت دارد كه اين ايما و اشاره ممكن است بركرفته از جهت

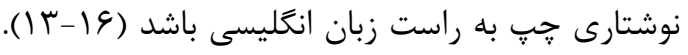

معرفى حوزهُ زمان انغاره Nunez و Cooperrider: آنها انغارهاى سه كانه كه شامل موارد زير مى باشد را معرفى مى كنند: زمان با نقطه

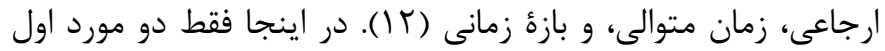
يعنى زمان با نقطة ارجاعى و زمان متوالى را كه بركرفته از انكارهٔ نوعالف و نوع-ب McTaggart مىباشند معرفى مى كنيم.

زمان با نقطهُ ارجاعى (Deictic-time): مشخصٔ زمانى خاصى

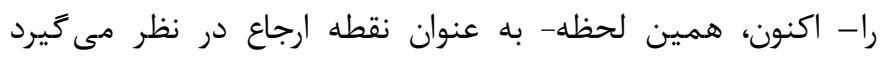

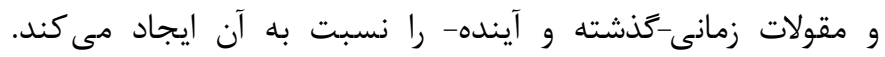

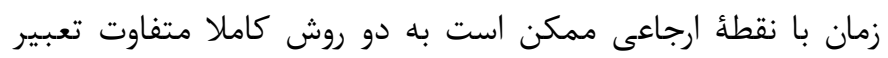
شود: يكى از منظر درونى به صورتى كه مركز ارجاعى-مشاهدهربه صورت ذاتى با الآن به حالت سرى همخوانى دارد (زمان با نقطه ارجاع درونى، شكل ( ب) كه به نظر مىرسد جهانى باشد، و ديخرى از منظر بيرونى به صورتى كه مركز ارجاعى در كانونى بيرونى واقع مىشود (زمان با نقطه ارجاع بيرونى، شكل ا الف).

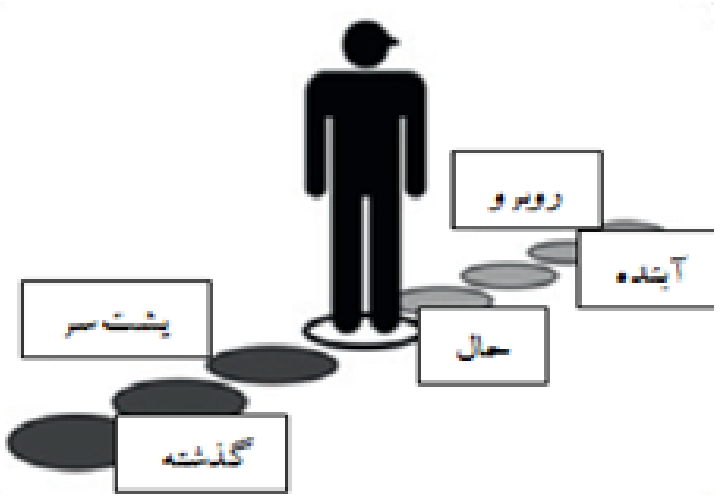

ب) زمان با نقطة ارجاع درونى

جهت نوشتارى به شدت بر نمونهسازى مفاهيم توالى زمان و زمان

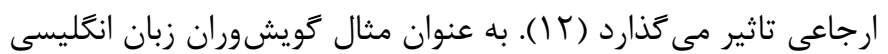

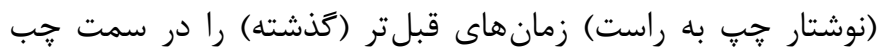

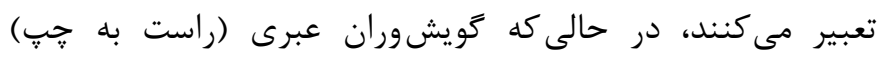
كذشته را در سمت راست تعبير مى كنند. اما با وجود غلبئ محور افقى، نكاشت كذشته و آينده به محور عمودى در مكان به صورت ركت

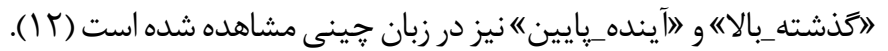

كذشته و راست بر آينده منطبق باشد (با، f). همجنين استعارههاى زبانى از قبيل اشب يلدا دارد نزديك مىشوده نمودى از استعاره زمان_متحرك (Moving-time) و جمله لاداريم به شب يلدا نزديك مى شويم" نمودى از استعاره شخص_متحرك (Moving-ego) در

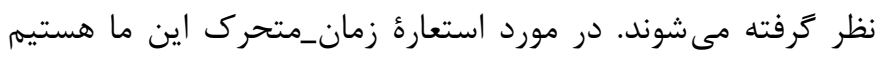

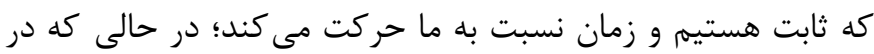

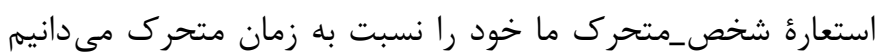

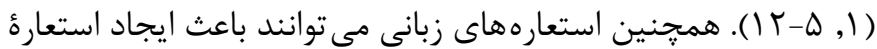
مفهومى و جارجوب ارجاعى افقى_سهمى (Sagittal-horizontal) رو به رو-هشت سر (Front-back) شوند. استعاره زبانى در جملاتى از قبيل "جمعأ خوبى پيش رو دارم" و يا "هفتأ سختى را يشت سر كذاشتم" بر اين استعاره دلالت دارند كه در خط ذهنى زمان، آينده در رو به روى شخص و كذشته يشت سر وى فرض مى شود. يكى

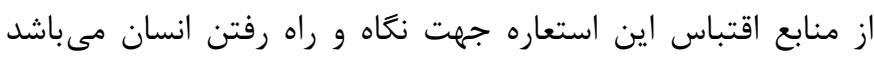

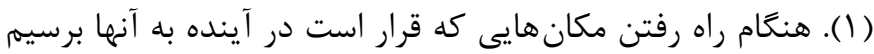
رو به روى ما قرار دارند و مكانهايى كه قبلا ديدهايم يشت سر ما ران قرار مى گيرند. اين كه جهت نوشتارى، جهت راه رفتن و جهت نحاه به عنوان منابع فضايى مىتواند بر مفهومسازى زمان در ذهن ما تاثير بكذارند در مواردى از قبيل ايما و اشارات كلامى (Co-speech (gestures

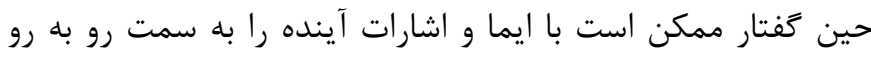

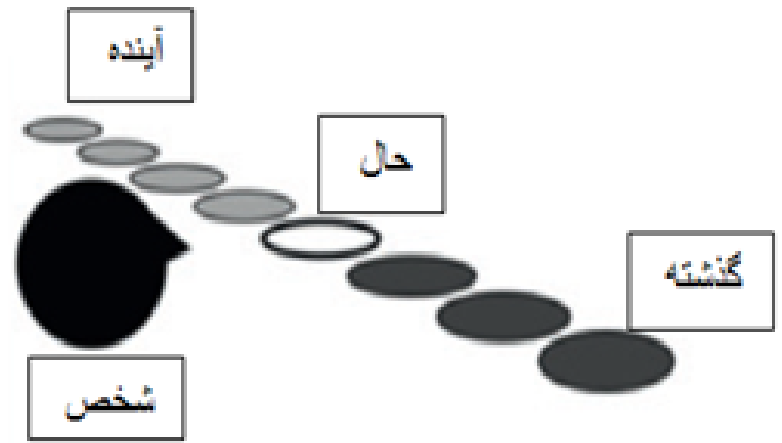

شكل (. الف) زمان با نقطهُ ارجاع بيرونى

زمان متوالى (Sequence-time): مربوط مىشود به رابطة بين

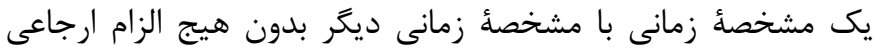
به زمان حال. با نبود الآن اجبارى_مركز ارجاعى_در واقع كذشته

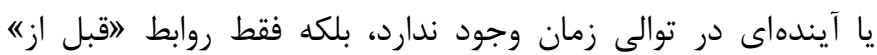

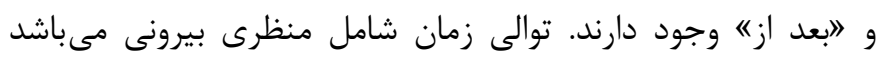

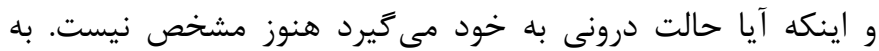
خاطر ماهيت ذاتا بيرونى (نقطه ارجاع بيرونى) نظامهاى نوشتارى، 


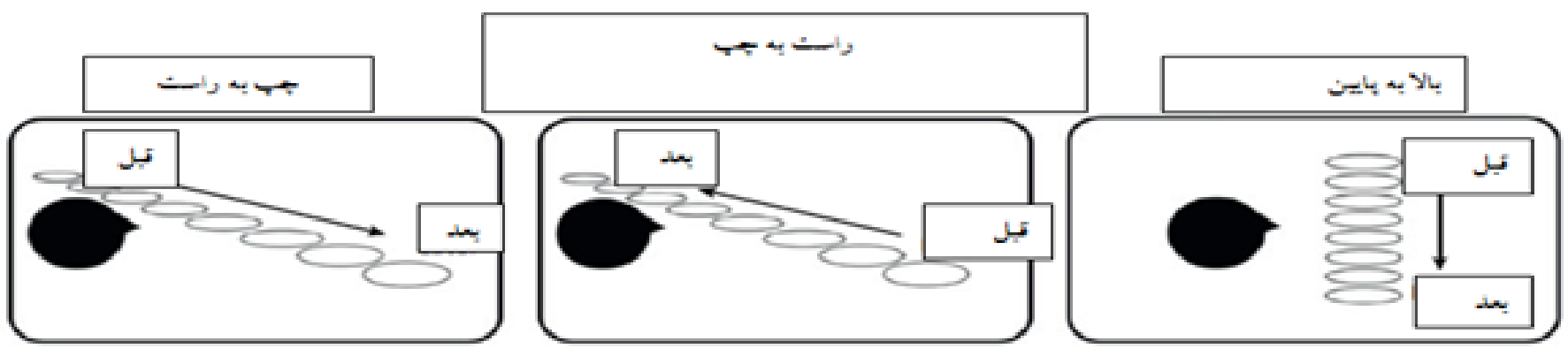

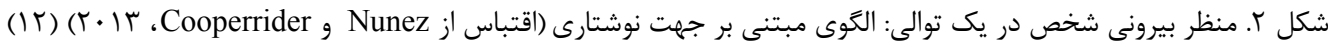

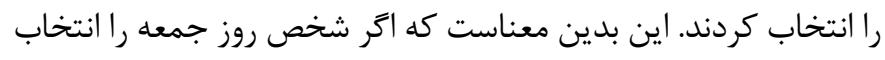
كند در واقع خود را به سمت آينده حركت داده است. اما اكر روز دوشنبه را انتخاب كند زمان را جابجا كرده است. Nunez را به دو دسته متفاوت شخص_محور و زمينه_محور تقسيمبندى مى كند، اعتقاد دارند كه زمان_متحرك و شخص_متحرك دو مورد از

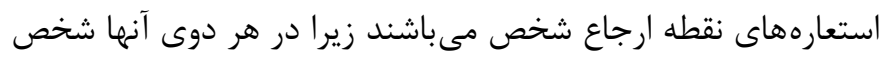
به عنوان مشاهده

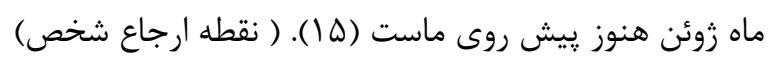

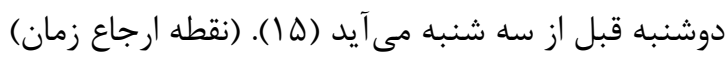

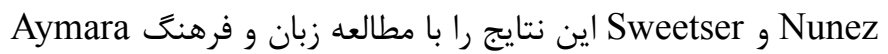
(بوليوى) به دست آوردند. آنها اعتقاد دارند نسبت دادن آينده به رو به رو و كذشته به يشت سر در زبان Aymara قابل تعميم نيست (ه|).

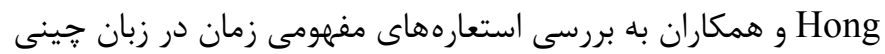
از طريق نمايش •F كلمه مربوط به زمان كذشته و •F كلمه مربوط به زمان آينده كه بر روى صفحه نمايش رايانه اجرا مى شد يرداختند.

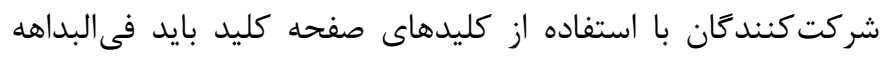
تصميم مى گرفتند كه كلمه كذشته يا آينده در قسمت بان بالا، يايين،

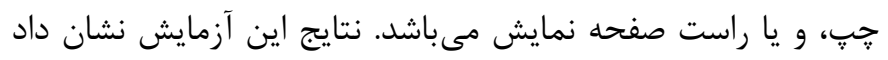

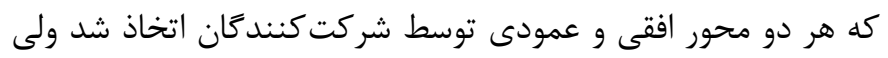
محور افقى به عنوان خارجوب غالب در نظر كرفته شد (rآ). نتايج آنها تا اندازماى با نتايج Bergen و همكاران تفاوت داشت (r). و همكاران با مطالعه خط ذهنى زمان در جينى هاى دو زبانه كه به

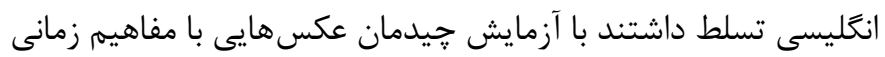
(مراحل رشد كياه، انسان، و غيره) دريافتند كه خط زمان به صورت

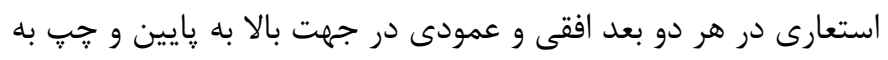

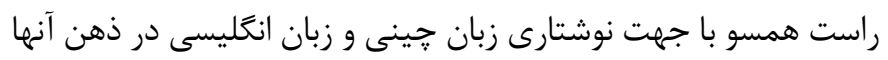

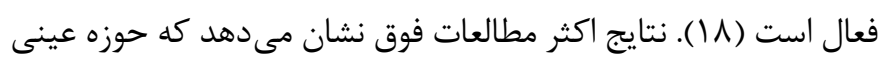

مفاهيم مرتبط به زمان الف) خطى، جرخهاى (Cyclical) و شعاعى (Radial): مفهوم خطى زمان با تجربهُ ما از گذر زمان و غير قابل بازگشت بودن رويدادها مطابقت دارد. مفهوم خرخهاى زمان با تجاربى از قبيل تكراريذيرى دورههاى زمانى كه به زندگى ما ساختار مىبخشند مطابقت دارد: مفهوم شعاعى زمان (شخص-محور) به ميزان دقت حافظه در به

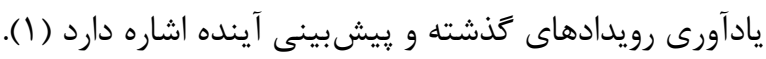
ب) بردار زمان (Arrow of time): بدين معنا است كه كذشته

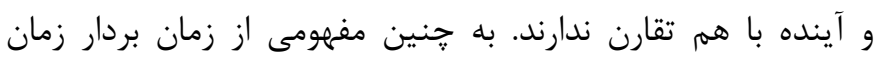

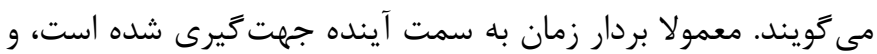
براى هر مفهوم طبق جنين تعريفى از زمان، رو به رو را به آينده نسبت

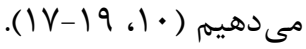

ج) خط ذهنى زمان (Mental time line): به نظر مى (ب) خد خط ذهنى زمان: () به حالت فضايى امتداد يافته است، ؟) تك بُعدى است، ؟َ) در

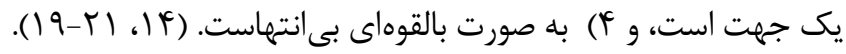

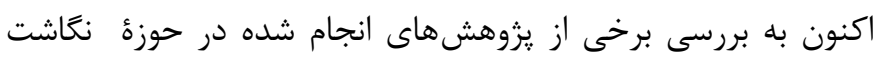

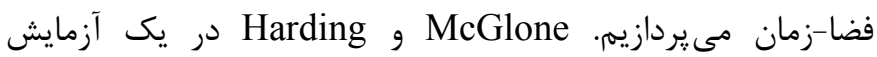
فراخوانى زبانى با طراحى يك جمله كه معروف به لآزمايش جلسه روز

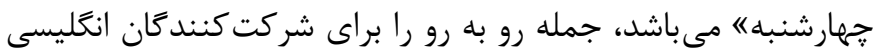
زبان به نمايش كذاشتند: "|"جلسهٔ جهارشنبأ هفتهُ بعد به دو روز جلوتر

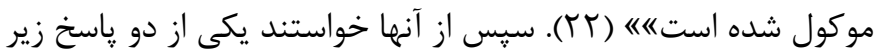

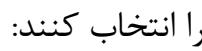
الف) جلسه در روز جمعه است. ب) ( بلسه روز دوشنبه است.

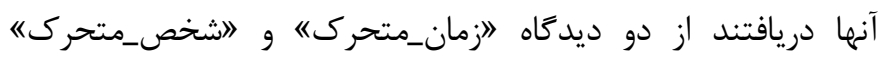

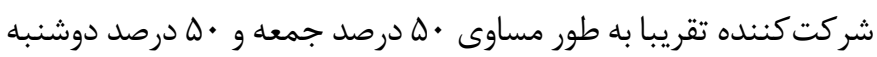




\section{() آزمايش كتبى آرايش وازگًان زبانى (Pederson و همكاران)}

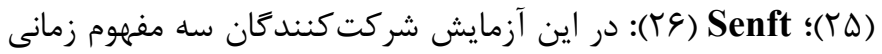
روزهاى هفته، ماهها، و فصل ها را در ستونهاى افقى عمودى و دايرهاى قرار مى دهند. الكوى هاى احتمالى در نمودارهاى ستونى عبارتند ازئ

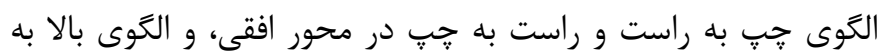
يايين و يايين به بالا در عمودى عمودى، و در الكَى دايرهاى دو حالت احتمالى ساعت گرد و پِادساعت گرد.

روزهاى هفته: شنبه، يكشنبه، دوشنبه، سه شنبه، جهارشنبه، ينجشنبه،

و جمعه
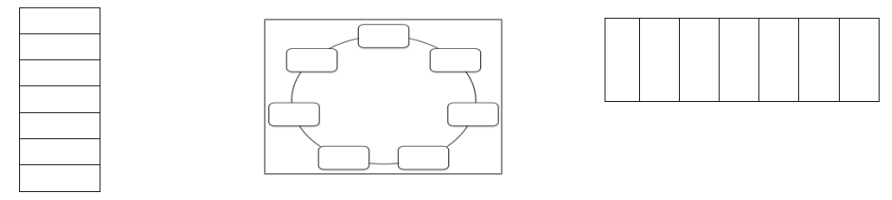

ماهها: فروردين، ارديبهشت، خرداد، تير، مرداد، شهريور، مهر، آبان، آذر، دى، بهمن، و اسفند
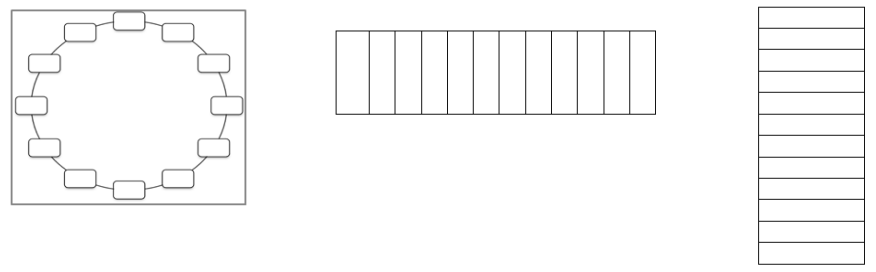

فصل ها: بهار، تابستان، باييز و زمستان
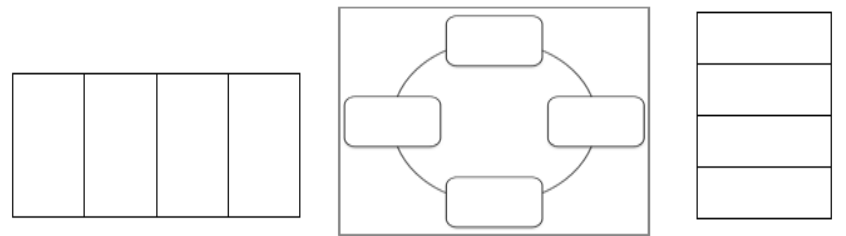

شكل r. آزمايش كتبى آرايش وازثكان زبانى

(T) آزمايش جينش مهرههاى حاوى وازٔكان زمانى (Brown) (TV):

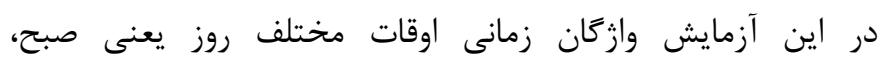

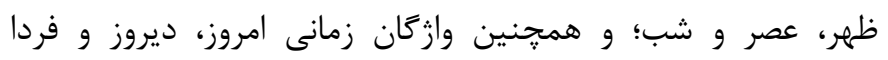
به صورت برجسب بر روى مهرههايى جسبانده شده است و از شركت كنندكان خواسته شد تا آنها را مرتب كنند. نكته اينجاست كه در وازگًان ديروز، امروز و فردا نقطه ارجاع مشخص مىشد و مهرهاى كه وازئ امروز بر روى آن نوشته شده بود به عنوان نقطه ارجاع به شركت كننده داده مى شد و از وى خواسته مى شعد تا نسبت به به امروز
فضا و نحوه مفهومسازى آن تاثير به سزايى بر نحوه مفهومسازى زمان

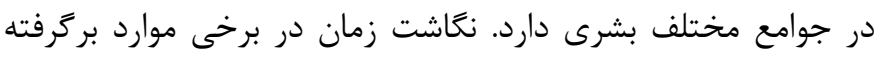

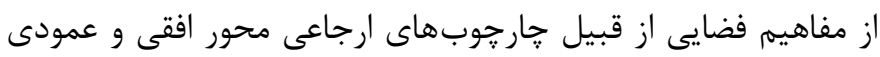

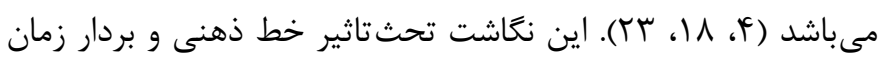
بازنمودهاى مختلفى در زبانهاى مختلف ايجاد كرده است. اكرجه جارجوب ارجاع فضايى_زمانى در جندين زبان مختلف انجام يذيرفته است ولى با توجه به دانش نكارنده به نظر مىرسد تا كنون مطالعات

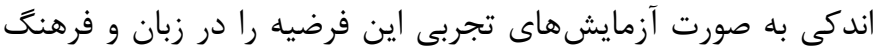
فارسى مورد آزمايش قرار داده باشند. در اين جستار برآنيم تا دريابيم فارسى زبانان با توجه به الكوهاى ارجاعى فضا از كدام קارجوب ارجاعى براى نكاشت زمان استفاده

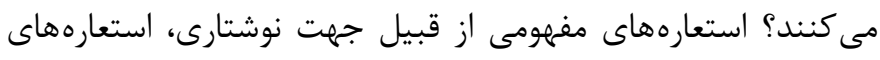

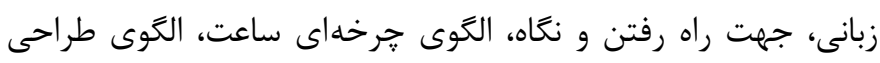

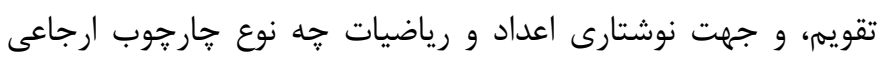
زمانى را در فارسى زبانان فعال مى سازند؟ غالبترين و فعال ترين منبع

اقتباس طبق آزمايشها زمانى طراحى شده كدام الكَوها مى باشند؟ لهن

\section{روش كار}

يزوهش حاضر به روش تجربى و با استفاده از شيوه آزمايشهاى و

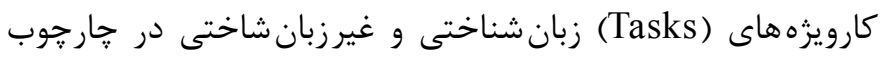

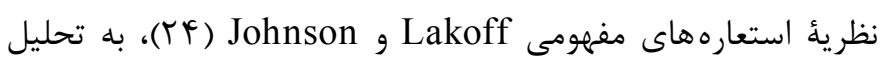

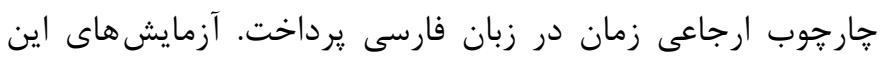

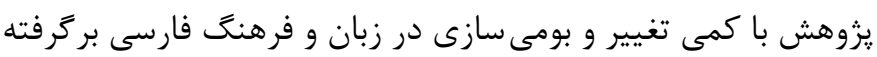

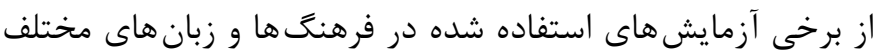
بود كه در ادامه با ذكر نام آزمايش مرجع آن نيز ذكر خواهد شد. از آنجايى كه جهت نوشتارى زبان و استعارههاى زبانى نقش مهمى در جيدمان مفاهيم زمانى دارند در اين تحقيق فقط از كويشوران

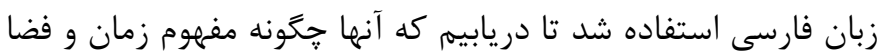

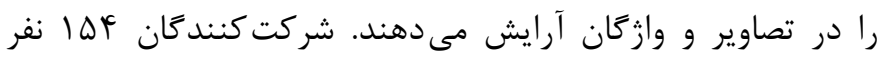

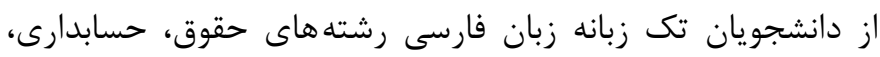

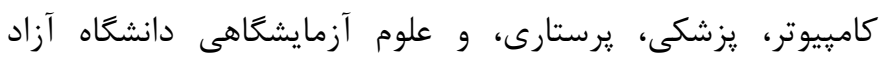
اسلامى واحد بين اللملى خرمشهر (خليج فارس) و دانشگاه علوم يزشكى آبادان بودند. سن، رشته تحصيلى، شغل و جنسيت به عنوان

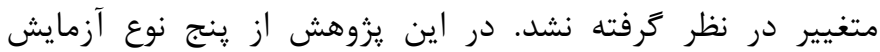

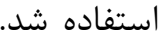
در ادامه به اختصار به ويزگى هاى آزمايشهاى انجام شده در اين جستار مى يردازيه. 
Brown رو-شتت سر معادل الكَى نزديك_دور يا دور-نزديك انغاره

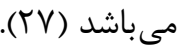

دو مهره ديروز و فردا را در موقعيت خاصى قرار دهد. لازم به ذكر است

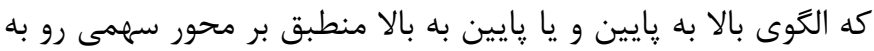
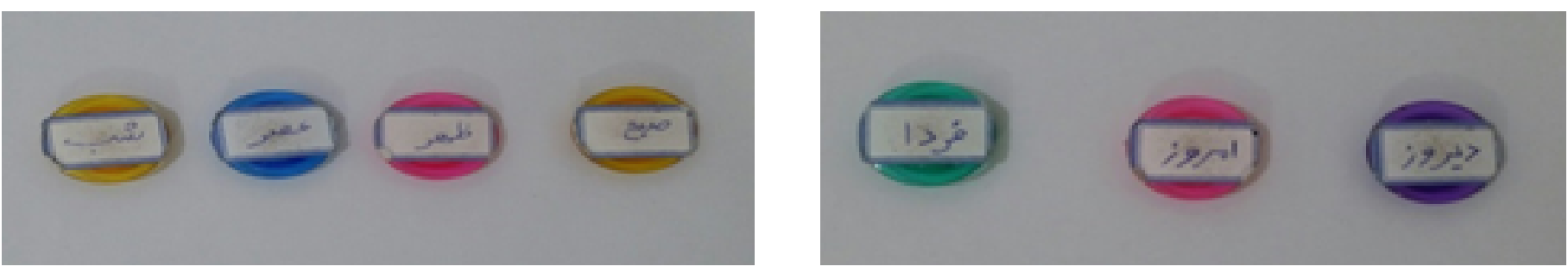

شكل F. جينش مهرههاى حاوى وازًّان زمانى

F) آزمايش غير زبانى با عكس (Bergen و همكاران) (َّ): در اين

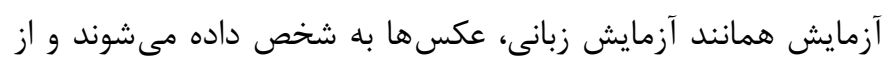
وى خواسته مى شود تا آنها را طبق يكى رابطه منطقى آرايش دهائ دهد.

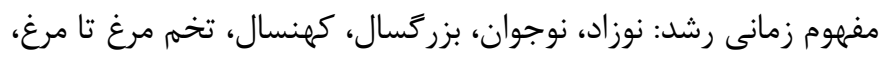

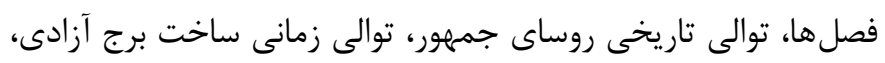

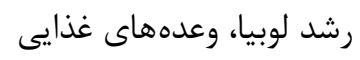

r) آزمايش زبانشاختى جمله (McGlone و (Harding) (Tr):

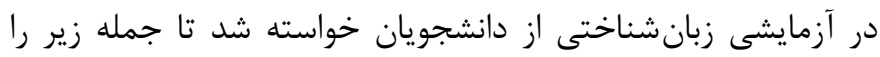

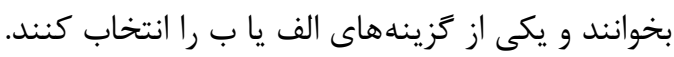

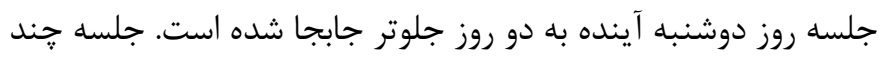

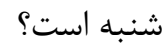

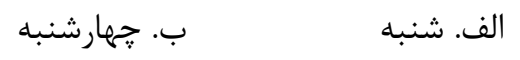
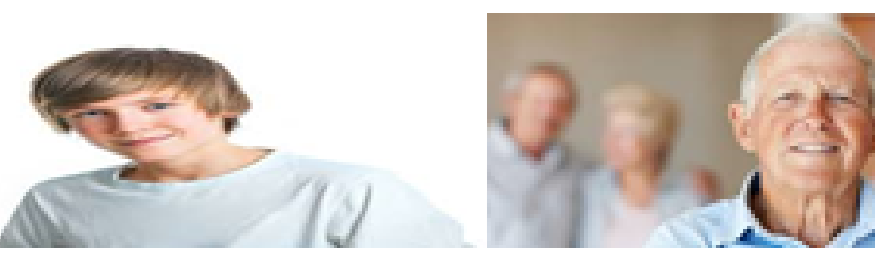

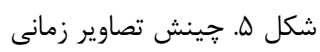

بافته ها در اين بخش تمامى دادههاى به دست آمده از هر آزمايش به تفكيك حدان در جداولى جداكانه ارائه مى كردند.

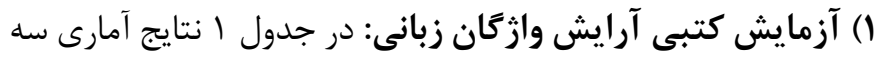

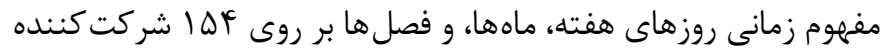
نشان داده شده است. به طور كلى نتايج و دادهاى آزمايش روزهاى

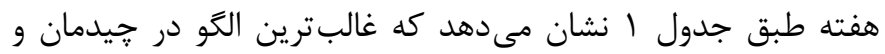
آرايش مفاهيم تقويمى محور عمودى بالا به پايين است كه بركرفته

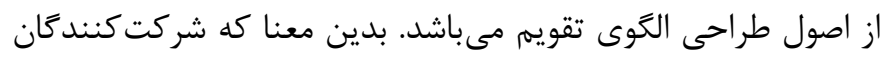

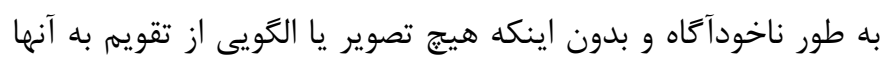

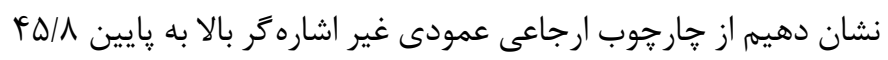

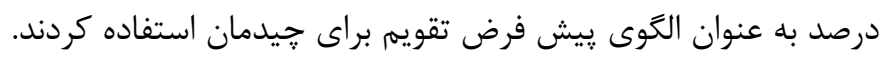

ه) آزمايش ايما و اشارات كلامى (Nunez و Sweetser) (هاد):

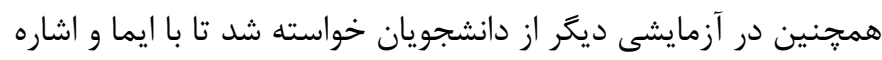

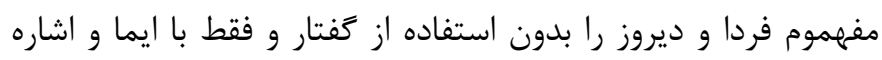
نشان دهند. نكته مهم در مورد هر آزمايش و مشاهده اين است كه هنغامى كه شركت كننده تصاوير يا وازًان را مرتب مى كند محقق بلافاصله جهت هر جينش را ثبت و ضبط مى كند و سِّ مسئله بعدى را براى حل كردن در اختيار شركتكننده قرار مى دهد. وازگًان و تصاوير درون

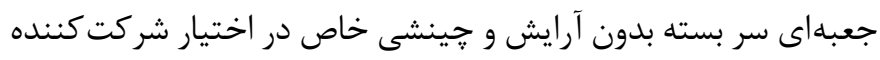

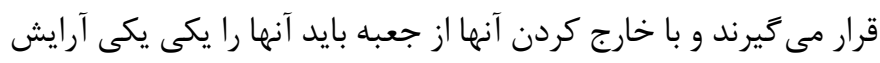

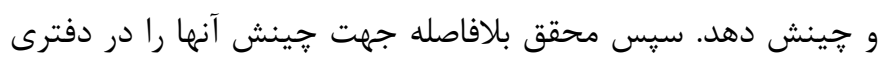

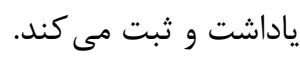


تكرار مى گردند. فصلها نتايج نسبتا متفاوتى در مقايسه با دو مفهوم هفتها و ماهها ارائه دادند. جارجوب ارجاعى محور جانبى راست به

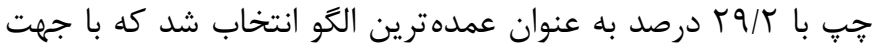

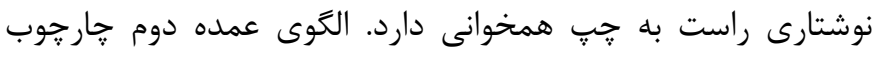

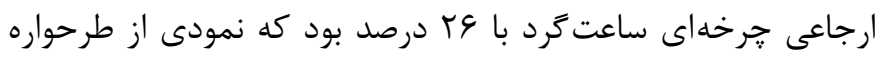

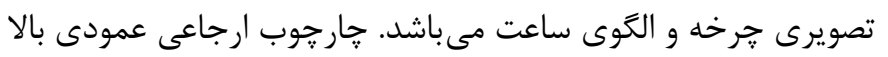
به پايين با س/رr درصد كه نمودى از الكوى طرح تقويم بود به عنوان

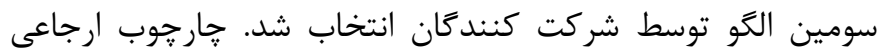

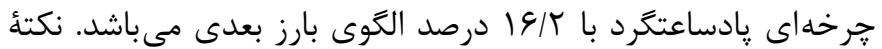

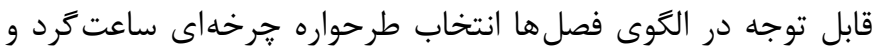

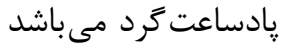
كه نسبت به موارد هفته ها و فصل ها بسامد بيشترى را نشان مى دهد؛ زيرا الكوى طرحواره خرخه ساعت گرد و پادساعت گر مجموعا روى هم

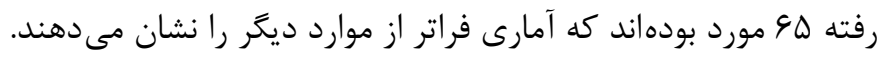

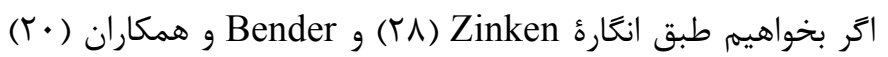
براى واحدهاى زمانى از قبيل روزهاى هفته، ماهها، و فصلها يك إنى روبروى ذاتى (ابتداى فواصل زمانى) در نظر بخيريم، مى توان براى تمامى موارد خطى يك روبرو را در نظر گرفت كه منطبق بر محور عقب/جلو باشد. همجنين از آنجايى كه تمامى موارد بالا به صورت توالى زمانى يكى پس از ديخرى بدون در نظر گرفتن هيج نقطه ارجاعى قرار

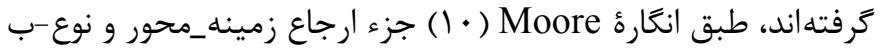
McTaggart Nunez (ه (1) جزء نقطه ارجاع زمان نوع-ب در نظر كرفته مى شوند.
در اين آزمايش، دادهها بر اين مسئله دلالت دارند كه آينده و رو به رو بر محور عمودى بدون نقطه ارجاع بالا به پايين انطباق دارند، يعنى

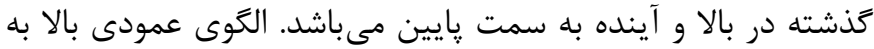
پايين همجنين ممكن است بركرفته از استعارئ نيروى جاذبه باشد كه در آن بالا معادل كذشته و پايين معادل آينده است.

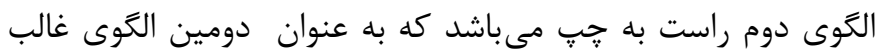
rQ/r درصد توسط شركت كنندكان انتخاب كرديد. اين الكو مى تواند دو منبع اقتباس داشته باشد: الكوى اصول طراحى يا الكَىى جهت نوشتارى. در ضمن اين الكو همجنين نشاندهنده توالى زمانى غير اشارهز بيرونى مى باشد. در مورد جينش ماهها به خاطر تنوع طراحى إنى الكَىى تقويمهاى روميزى، ديوارى، و يا سالنامه اگر در اينجا فقط

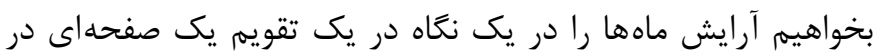

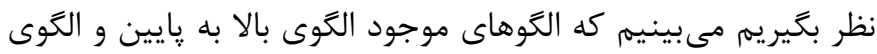

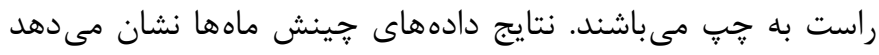

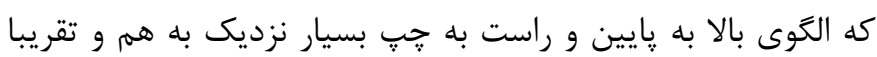

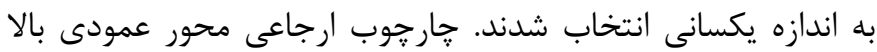

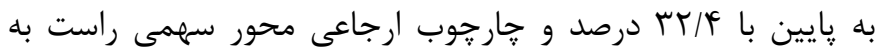
جֶٍ با //اب درصد دو الكوى غالب را نمايش مى دهند. اكرجه الكوى ساعت گرد و يادساعت گرد الكوهاى معمول و رايجى در تقويمهاى زبان فارسى نيستند، ولى الكوهاى سوم و جهارم به ترتيب جار جوب ارجاعى

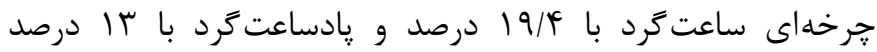
انتخاب شدند. الكَوى ساعت كرد و يا پادساعت كرد بيانكر جرخهاى بودن ماهها به صورت مدور هستند كه تقريبا به صورت سى روزه

جدول ا. نتايج آمارى سه مفهوم زمانى روزهاى هفته، ماهها و فصلها

\begin{tabular}{|c|c|c|c|c|c|c|c|c|c|}
\hline رٍَّ به & به جِ & بالا بين & ساعت گرد & يادساعت گرد & 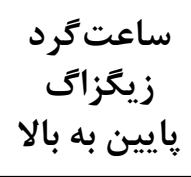 & 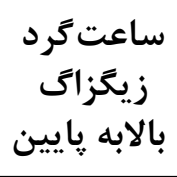 & 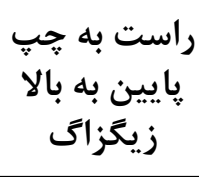 & 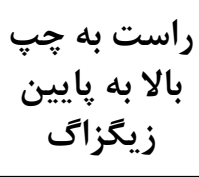 & كتبى آزمايش \\
\hline 1 & rq & 99 & TD & 10 & 1 & r & . & . & هفته \\
\hline$r$ & $\Delta$. & $4 q$ & $r$. & $r \cdot$ & . & r & . & . & ماهها \\
\hline 1 & Fa & rq & r. & TQ & r & f & 1 & r & فصلها \\
\hline $1 / 98$ & fe/qG & D & r1/99 & $r$. & 1 & $r / 98$ & rr/. & .19 & ميانگين كل \\
\hline $1 / \cdot 1$ & rq & זr/זr & $r \cdot 109$ & ir & .194 & r/TA & $\cdot|r|$ & $\cdot 1 / 9$ & درصد كل \\
\hline
\end{tabular}




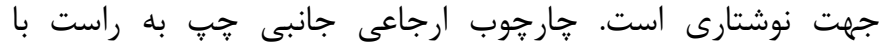

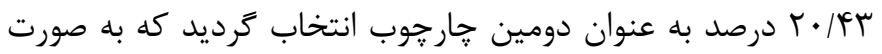

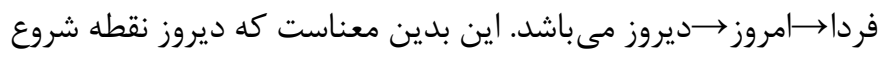

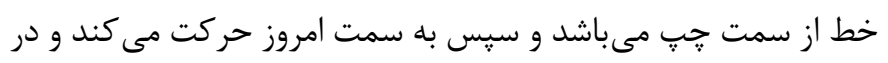

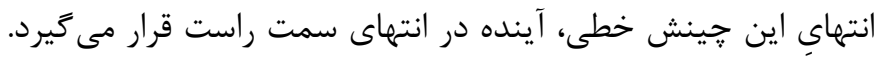

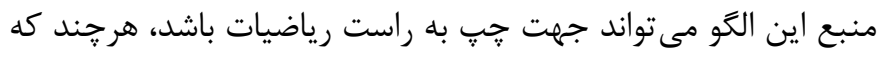

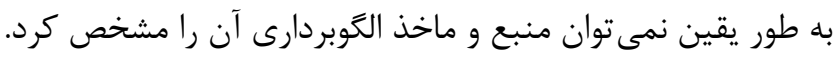

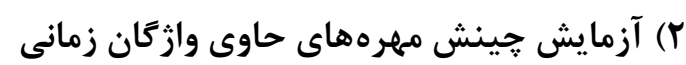

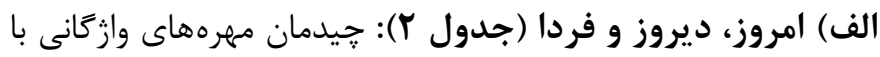

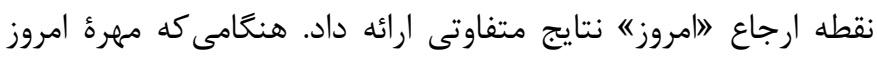

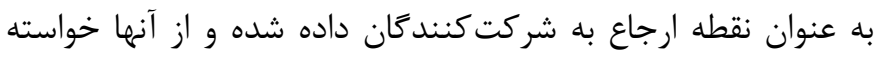

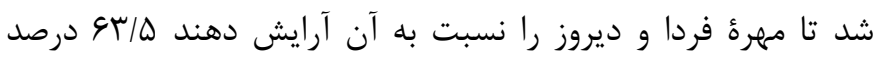

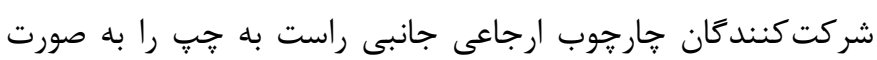

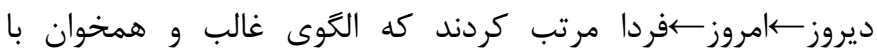

جدول r. غالب بودن محور افقى-جانبى راست به جֶٍ همسو با جهت نوشتارى زبان فارسى

\begin{tabular}{|c|c|c|c|c|c|c|c|}
\hline نزديك-دور & دور -نزديك & جֶ-راست & راست-جي & ساعت گرد & يادساعت گرد & مفاهيم زمانى & \\
\hline 9 & it & rA & Av & . & 1 & ديروز، امروز، فردا & آزمايش زبانى \\
\hline 11 & iv & re & $\Delta 4$ & 1 & · & صبح، ظهر، عصر، شب & \\
\hline 1. & $\mid F / Q$ & re & $\Lambda \Delta / \Delta$ & $\cdot / 0$ & $\cdot / \Delta$ & & ميانگين تعداد كل \\
\hline$V / r$. & $1 \cdot 19$ & 19 & $g r / F$. & 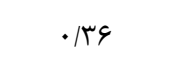 & . & & درصد كل \\
\hline
\end{tabular}

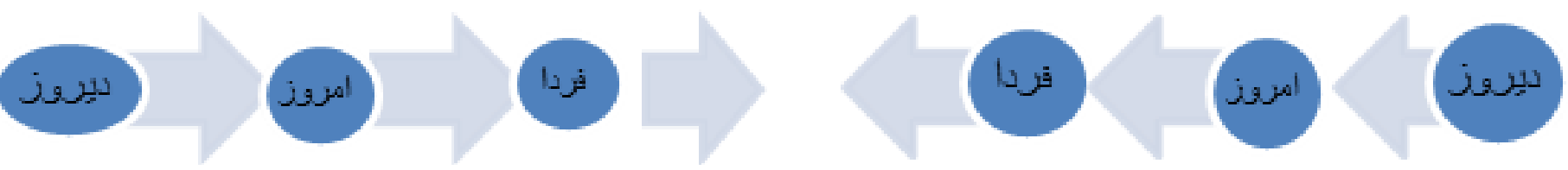

شكل 9. جينش مهرههاى زمانى تحت تاثير جهت نوشتارى زبان از راست به حٍ و جهت نوشتارى رياضيات و اعداد از جٍ به راست

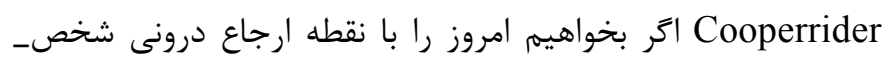

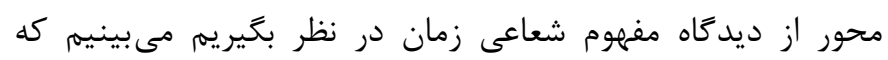

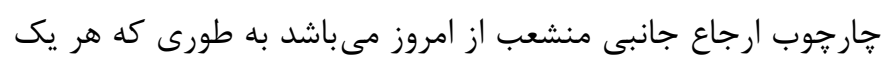

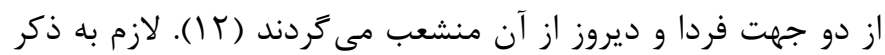
است كه اين بدين معنا نيست كه ديروز به سمت كذشته جريان دارد. بلكه بدين معناست كه خط زمان از ميان شخص عبور مى كند ولى

$$
\text { از او نشات نمى كيرد. }
$$

جارجوب ارجاعى سهمى دور-نزديك (بالا_يايين) با N/VD درصد

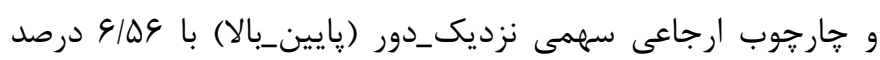

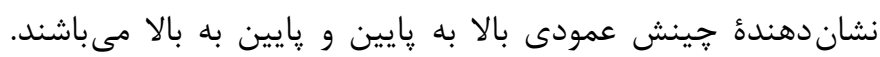

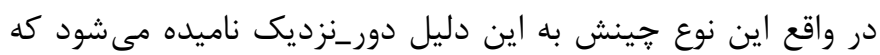

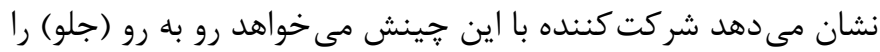
مشخص كند. ارجاع سهمى نزديك_دور (يشت سر به رو به رو) ساز كار با جهت راه رفتن و استعاره زبانى مى باشد. طبق انغاره مunez و

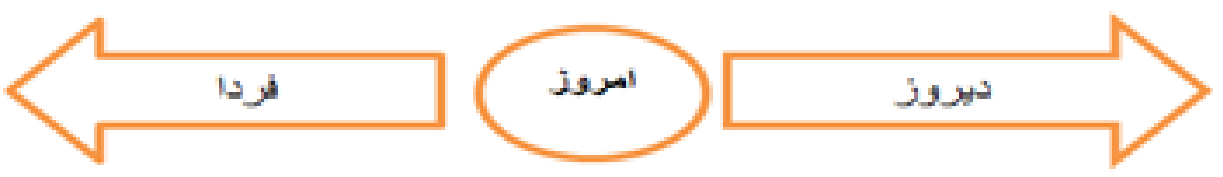

شكل V. مفهوم شعاعى زمان با ارجاع جانبى شخص محور 
رياضيات باشد ولى رياضيات و اعداد از جهت جٍٍ به راست به عنوان يكى از منابع الكوبردارى براى اين نوع جيدمان مى باشند. جارجوب

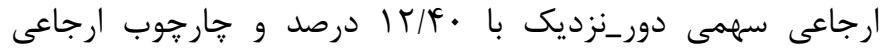
سهمى نزديك_دور با N/T درصد همسو با جهت راه رفتن و استعاره

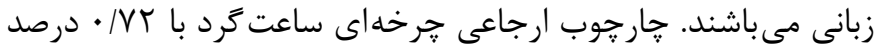
جزو الكوهاى بسيار كم بسامد انتخاب شد. اين نكته نشان مى دهد

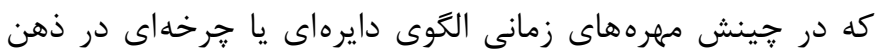
فارسى زبانان نمود بسيار كمترى دارد
ب) جيدمان صبح، ظهر، عصر، و شب (جدول ؟): جارجوب

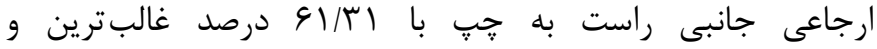
يربسامدترين جينش خطى_جهتى را به خود اختصاص داد كه همسو با جهت نوشتارى زبان فارسى است؛ طبق انغاره Nune و Cooperrider

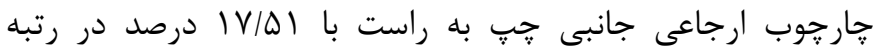

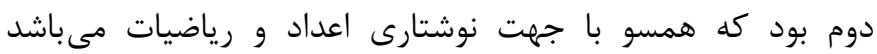
اگرجه نمى توان با قطعيت كَفت كه اين جِينش بركرفته از الكوى

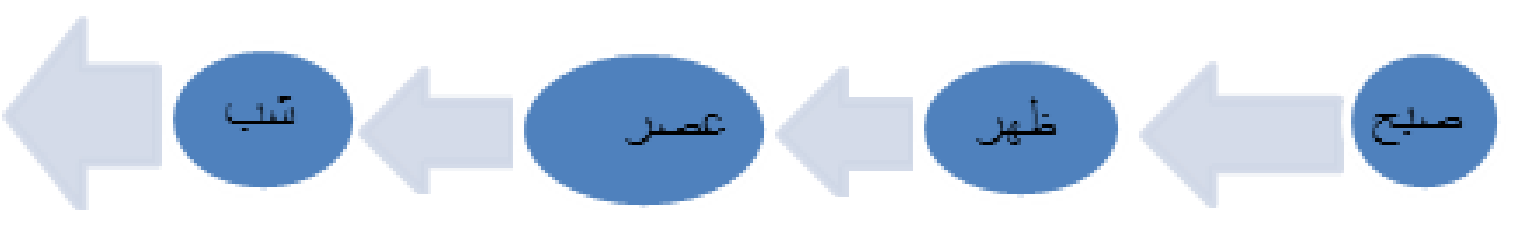

شكل ^ـ غالب بودن الكَوى جهت نوشتارى زبان از راست به حٍٍ

خود را به عنوان نقطه ارجاع معادل دوشنبه در نظر گرفتهاند و نسبت به آن جلسه را به دو روز جلوتر يعنى جهارشنبه منتقل كردند كه از استعارٔ مفهومى شخص_متحرك بهره جستهاند. اين در حالى است كه

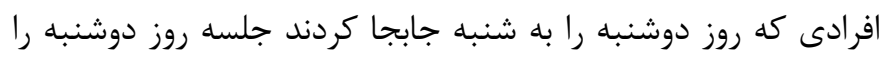
دو روز جلوتر به سمت خود كشيدهاند كه به نوعى بهره كيرى از استعارئ مفهومى زمان_متحرك مى باشد. لازم به ذكر است كه شخص_متحرك و زمان_متحرك در آزمايش جلسه روز دوشنبه طبق انغارء McTaggart هر دو جزو نوع-الف مى باشند كه از نوع اشارهخر تلفى مى گردند. و طبق انغاره Nunez و هooperrider هر دو الكً از نوع زمان با نقطه ارجاع درونى مىباشند (r) (I). r) ( آزمايش زبانشاختى جمله آزمايش جابجايى جلسه روز دوشنبه با دو هدف طراحى شد. ()

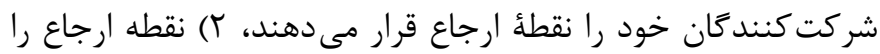
روز دوشنبه در نظر مى گيرند. به عبارت ديخر اخر شخص جلسه روز

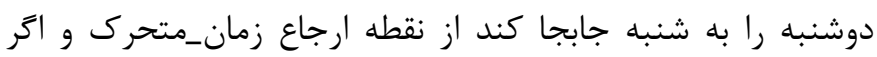

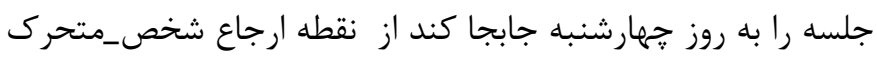

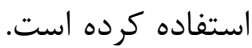
نتايج اين آزمايش نشان داد كه /ץ/• ع درصد شركت كنندكان جلسه را به روز جهارشنبه و ا/// درصد ديخر جلسه را به روز شنبه جابجا كردند. در اين آزمايش افرادى كه جلسه را به روز جهارشنبه جابجا كردند

جدول r. جا به جايى جلسه روز دوشنبه به شنبه (حركت-زمان) يا جهارشنبه (حركت-شخص)

نقطه ارجاع حركت زمان-حركت شخص جلسه روز دوشنبه آينده به دو روز جلوتر جا به جا شد. جلسه جند شنبه است؟

9)

५ /9)

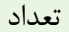

( - مرصد

تعداد

درصد
شنبه (حركت-زمان)

جهارشنبه (حركت-شخص) 


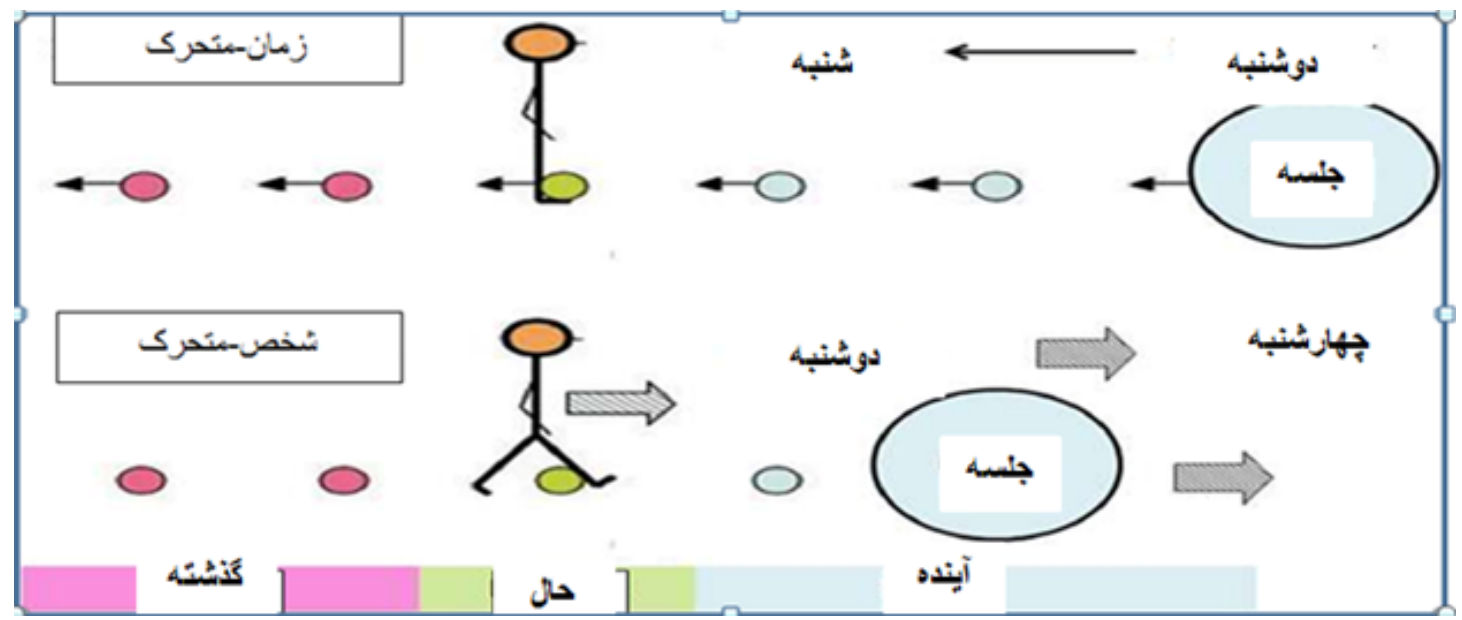

شكل ^. نمايش جابجايى جلسه روز دوشنبه به شنبه يا جهارشنبه از طريق شخص_متحرك و يا زمان_متحرى

مرتبسازى ديگر تصاوير ارائه داد كه بر غالب بودن استعاره جهت نوشتارى در اين آزمايش صحه كذارد. اين بدين معناست كه جهت زبان نوشتارى به عنوان يك قراداد فرهنگى بر نحوه و جهت جيدمان تصاوير زمانى تاثير مى گذارد. نتايج مرتبسازى تصاوير فصلها در جدول \& تا حدى همسو با نتايج جدول ا مىباشد. زيرا در جدول 1

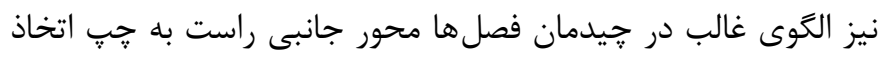
شد كه همانند نتايج اين آزمون همسو با جهت نوشتارى بوده است. لازم به ذكر است كه طبق انغاره Nunez و Cooperrider (I ) جيدمان عكس ها از نوع زمان متوالى با منظر بيرونى تلقى مى شوند.
F) آزمايش غير زبانى با عكس و تصوير در اين قسمت هفت نوع آزمايش مفاهيم مختلف زمانى طراحى شد تا ترتيب جيدمان جارجوب ارجاعى از بين VI ا شركت كننده مورد آزمايش و بررسى قرار گيرد. در اين آزمايش از عكس به عنوان ابزار آزمايش استفاده شد. طبق جدول ^ا مرتبسازى تصاوير زمانى نشان

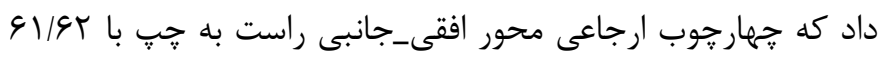
درصد به عنوان :ربسامدترين الگوى انتخاب شد كه همسو با جهت نوشتارى زبان فارسى است. حتى آزمايش وعدههاى غذايى صبحانه، ناهار و شام با نقطه ارجاع ناهار نيز نتايج بسيار مشابهاى همانند

جدول f. مرتبسازى تصاوير زمانى و غالب بودن محور افقى_جانبى راست به حٍ همسو با جهت نوشتارى زبان فارسى

\begin{tabular}{|c|c|c|c|c|c|c|c|c|}
\hline نزديك -دور & دور-نزديك & جֶׁ-راست & راست -جٍ" & زيا زيَين بالا & ساعت گر د & يادساعت گرد & مفاهيم زمانى & \\
\hline$\Delta$ & ir & rI & $\wedge \varepsilon$ & r & r & 4 & بهار، تابستان، هاييز،زمستان & \& \\
\hline$\Lambda$ & 11 & TQ & 19 & · & · & r & صبحانه، ناهار، شام & \\
\hline$\checkmark$ & 19 & rq & Af & 1 & · & · & روساى جمهور & כ \\
\hline 4 & 11 & rq & $\wedge \vee$ & 1 & 1 & r & جوان، مرغم مرغ، جوجه، جوجه & 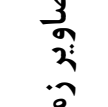 \\
\hline IV & 9 & rq & $\wedge$. & r & • & • & لوبيا لوبيا، جوانه لوبيا، كياه & $y$ \\
\hline 9 & IV & tr & Ar & r & $\cdot$ & $\cdot$ & 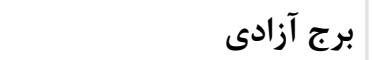 & \\
\hline ir & 11 & r. & N & - & 1 & · & كهزيسال، نوجوان، بزركسال، & \\
\hline $9 / \Gamma \wedge$ & $I T / \Delta V$ & $r V / I F$ & $\Lambda F / F T$ & $1 / T \wedge$ & $\cdot|V|$ & $1 / V 1$ & \multicolumn{2}{|c|}{ ميانگين تعداد كل } \\
\hline G/VV & $9 / 1 V$ & $19 / 11$ & GI/Gr &.$/ 94$ & $\cdot|0|$ & $1 / \pi \Delta$ & \multicolumn{2}{|c|}{ ميانكين درصد كل } \\
\hline
\end{tabular}


درصد به عنوان عمدهترين الكو استفاده شد. خارجوب ارجاعى محور سهمى رو به رو همخوان با جهت راه رفتن انسان و استعاره زبانى با 

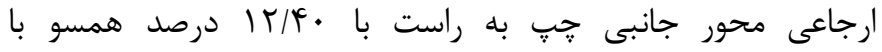

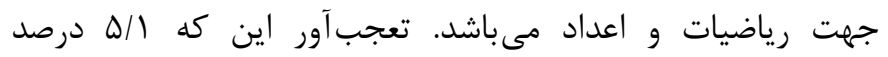

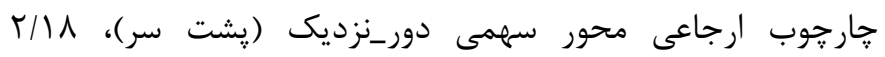

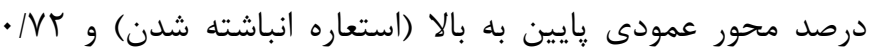
درصد محور سهمى دور به نزديك را به عنوان خارجوب ارجاعى خود

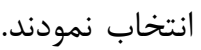

ه) آزمايش ايما و اشارات كلامى در اين آزمايش افراد بدون استفاده از كلام و فقط با ايما و اشاره به حالت تقريبا يانتوميم مىبايست به دو مفهوم ديروز و فردا اشاره مى كردند. به صورت فرضى از آنها خواسته شد تا با ايما و اشاره جلمة لفردا مى بينمته

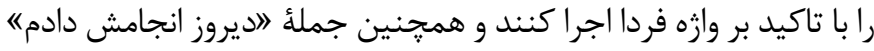
با تاكيد بر اجراى وازه ديروز.

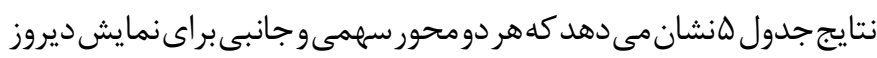
و فردا توسط شركت كنندكان اتخاذ شدند. براى نمايش مفهوم زمانى فردا

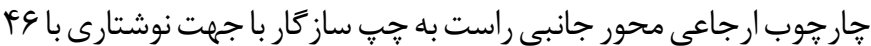

جدول ه. دو مفهوم زمانى فردا و ديروز در ايما و اشارات كلامى

\begin{tabular}{|c|c|c|c|c|c|c|c|c|}
\hline راست-جي & جֶب-راست & بالا & رو به رو & يشت سر & دور-نزديك & فراوانى & دو مفهوم زمانى & \multirow{5}{*}{ ايما و اشاراتى } \\
\hline qr & IV & r & is & V & 1 & تعداد & \multirow{2}{*}{ فردا } & \\
\hline iq & $\mid r / 4$ & $T / r$ & 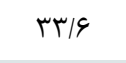 & $\Delta / 1$ & $\cdot / V r$ & درصد & & \\
\hline$\wedge$ & $r \cdot$ & . & r & $1 \cdot r$ & r & 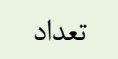 & \multirow{2}{*}{ ديروز } & \\
\hline$\Delta / \Lambda$ & 10 & . & $1 / 4 \Delta$ & $V \Delta / / \Lambda$ & $r$ & درصد & & \\
\hline
\end{tabular}

بحث مواردى را كه مى توان طبق دادههاى به دست آمده مورد بررسى و بحث قرار داد عبارتند از: مفهوم و جهت رو به رو، جهت و ابعاد خط ذهنى زمان، جهت نوشتارى، الكوى جرخهاى تقويم، جهت راه رفتن، و استعاره زبانى. اين موارد به عنوان اصلىترين استعارههاى تاثيرگذار بر نگاشت زمانى طبق فرضيات مختلف ارائه شده به حساب مى آيند. نتايج نشان مى دهد كه فارسىزبانان از محورهاى عمودى و افقى در نحَاشت مفاهيم زمانى كه بركرفته از جهت نوشتارى، جهت نگاه و راه رفتن، الخوى طراحى تقويم و سالنامه، الكوى جرخهاى ساعت، و همجنين جهت نوشتارى رياضيات مىباشند، به عنوان منابع اقتباس بهره مى جويند. در حال حاضر با توجه به دادههاى اين آزمايشات و طبق فرضيات ارائه شده توسط Nunez و Bender و همكاران (1) Cooperrider (1) به نظر مىرسد جهت نوشتارى راست به جֶٍ زبان فارسى عمدهترين منبع اقتباسى استعارههاى مفهومى زمان در شركت كنند راه رفتن يا جهت نخاه يعنى محور سهمى رو به رو مىباشد كه همسو با جهت آينده در خط فرضى زمان و استعارههاى زبانى است. بسته به طراحى آزمايش و نوع مفهوم زمانى مورد آزمايش، محور اقتباسى و منبع اقتباس متفاوتى اتخاذ مىشود. در واقع مى توان گفت كه نوع آزمايش تا
نتايج وازه مفهومى ديروز اما كمى متفاوت بود. VD/ \ درصد محور سهمى دور-نزديك (يشت سر) ناهمخوان با جهت راه رفتن را انتخاب نمودند و ها درصد محور جانبى جٍ به راست را به عنوان دومين جارجوب ارجاعى خود در نظر كرفتند. محور جانبى راست به جٍٍ ساز گَار با جهت نوشتارى با ه/ه درصد به عنوان جار جوب ارجاعى سوم استفاده شد. محور

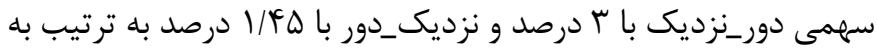
عنوان جار جوب هاى جهارم و ينجم در نظر گرفته شدند. نكته قابل توجه در مورد تفاوت اتخاذ محور سهمى دور نزديك با VQ/M درصد و مجددا محور سهمى دور نزديك با س درصد اين است كه در مورد اولى افراد با دست يا انخشت شست خود به يشت سر اشاره نمودند به طورى كه آن را تا بالاى شانه و كنار گوش يا نزديك سر مى آورند و به يشت سر اشاره مى كردند ولى در مورد دومى افراد دست يا انخشت سبابه را جلوى سينه

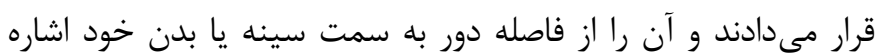
مى كردند. در ضمن مفهوم شعاعى زمان جه در مورد محور سهمى و جهـ در مورد محور جانبى نيز از اين آزمايش برداشت مىشود. همجنين اين دو محور همسو با توالى زمان به صورت شخص_محور با مركز اشارهز

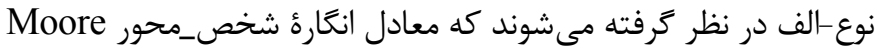
(•) (1) معادل استعاره نقطه ارجاع Nunez (ه ) مىباشند. 


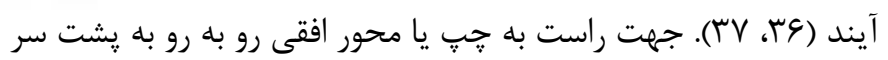
به اين معنا نيست كه خط زمان جنين جهتى دارد بلكه بدين معناست كه خط ذهنى زمان متاثر از تجارب شناختى و ذهن بدن مند ما وابسته به نوع آزمايش مى تواند الكو و جيدمانى از آن جهت ها به عنوان مثال جهت نوشتارى زبان -راست به جِّ- يا جهت استعارههاى زبانى -رو به رو به

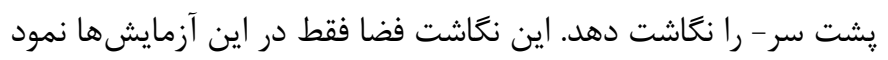
داشته و تا زمانى كه علم عصبشناسى شناختى در اين حوزه متغيرهاى ديخر (ج) ٍ دست، راست دست، جنسيت، سواد، و غيره) را رد يا تاييد نكند خط ذهنى زمان همجنان الكوى كاملا مشخصى نخواهد داشت و

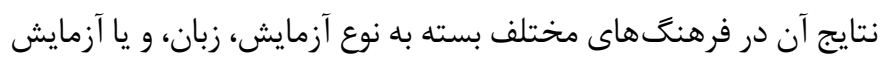

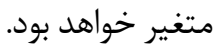

\section{نتيجبه كَيرى}

استعارههاى مفهومى زمان به عنوان يك مفهوم شناختى در حوزه نغاشت فضا و زمان در حال حاضر نياز به تحقيقات بيشترى دارند تا يك الگو و جارجوب نظرى مشخص و واحدى براى آنها ارائه گردد. اگر جه گالتون نقد شديدى بر نگاشت فضا و زمان دارد و اعتقاد دارد كه مشخصات فضا به طور كامل نمىتوانند در حوزه زمان نگاشت داشته باشند ولى نكاشت فضا و زمان توسط بسيارى از دانشمندان شناختى اين حوزه با وجود تنوع و گوناگونى مدلهاى ارائه شده مورد تصديق قرار كرفته است. شايد بتوان با توجه به نتايج آزمايشات اين تحيق جنين بيان كرد كه خط ذهنى زمان به عنوان يك مفهوم استعارى برى بسيار تحت تاثير محور جانبى راست به جٍٍ مىباشد كه برگرفته از

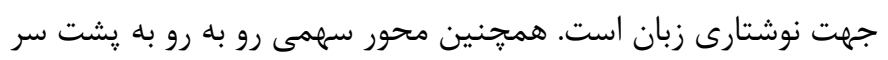
از جهت راه رفتن و نگاه و جهت استعارههاى زبانى اقتباس شده است. و در آخر محور جانبى جֶٍ به راست بركرفته از جهت نوشتارى رياضيات و اعداد ايجاد گرديد. نتايج نشان مى دهد كه خط ذهنى زمان تحث تاثير نوع آزمايش، زبان و شرايط فرهنغى ممكن است متغيير باشد.

\section{تشكر و قدردانى}

از داوران ناشناس مجله محترم تازههاى علوم شناختى به خاطر نظرات و ييسنهادات دقيق و ارزنده كه باعث استحكام مفهومى مقاله كرديد كمال تشكر و قدردانى را داريم. اين مقاله مستحرج از رساله دكترى زبانشناسى همخانى دانشخاه آزاد اسلامى واحد آبادان با كد

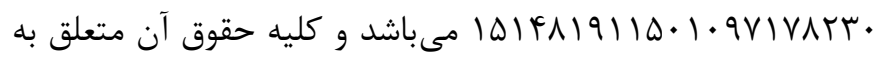
آن واحد دانشخاهى مى باشد. همجنين نويسندگًان اين مقاله هيج گونه تضادى در منافع اين مقاله با يكديگر ندارند.
حد بسيار زيادى تعيين كننده محور، جارجوب ارجاعى، و منبع اقتباسى اتخاذ شده مىباشد. اين بدين معناست كه به طور قطع نمىتوان كفت فارسىزبانان كدام محور، جار جوب، يا منبع را به طور هميشكى و به عنوان يك اصل در مفهومسازى زمان به كار مى گيرند. اما شايد بتوان گفت كه نتايج اين يزوهش تا حد زيادى بر اين تاكيد دارد كه جهت نوشتارى زبان تاثير زيادى بر جيدمان مفاهيم زمانى در آزمايشات زبانى و عكس نشان

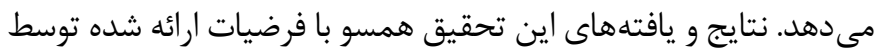
Nunez نكتئ مبهمى كه در مورد محور جانبى جֶٍ به راست وجود دارد اين است كه به طور حتم نمى توان كفت منبع اقتباس اين محور واقعا جهت نوشتارى اعداد و رياضيات باشد. شايد منبع ناشناخته ديخرى باعث ايجاد اين بعد و جهت شده است (مثلا آموزش زبان انكَليسى). همجنين محور عمودى بالا به يايين منبع اقتباس معينى ندارد. Shinohara (• • إ) اعتقاد

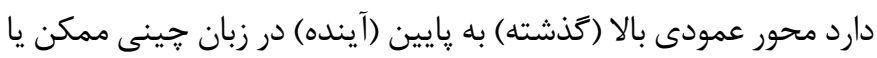
بركرفته از جهت نوشتارى زبان جينى ماندارينى باشد كه از بالا به يايين

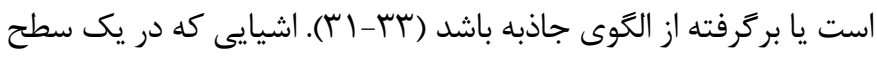
شيبدار غلت مى خورند، كذشته در قسمت بالاى شيب و به خاطر نيروى جاذبه، آينده در قسمت يايين قرار مى گيرد. نام ديخر اين انگاره الخوى

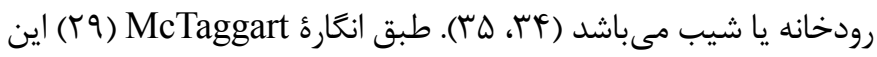
ارجاع جزو نوع-ب و طبق انگاره Nunez و Cooperrider (rأ) جزو توالى زمانى غير اشارهزر بيرونى مى باشد. مسئلئ ديكرى كه آزمايشات فضايى_زمانى نتوانستهاند مورد آزمايش و مشاهده قرار دهند مفهوم كذرايى يا فرّار بودن زمان طبق انگاره

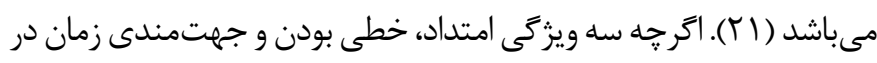
اين تحقيق نيز تاحدى تاييد شدند ولى اين بدين معنا نيست كه ويزگى هاى زمان كاملا با ويزگى هاى فضا انطباق دارند، بلكه بدين معناست كه اين سه ويزگ ويزگ

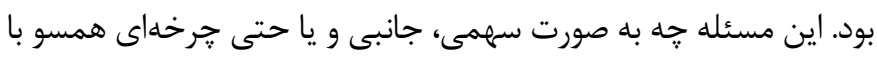
جهت ها و ابعاد خط ذهنى زمان نمود داشت. بنابراين به نظر مىرسد خط زمان به عوامل گوناگونى مانند بافت، ويزگى هاى خاص آزمايش، ذهنيت، فناورى ها و قرارداهاى فرهنگى بستخى داشته باشد.

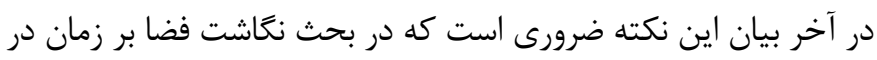
حال حاضر مواردى كه بر جيدمان تصاوير، كلمات، يا حتى ايما و اشارات زمانى ما تاثير مى گذارند غالبا بر گرفته از تاثير كانونى (Canonical) (effect

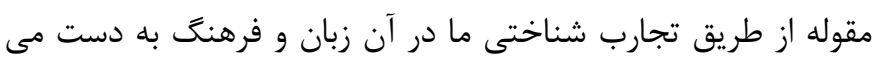




\section{References}

1. Bender A, Beller S. Mapping spatial frames of reference onto time: A review of theoretical accounts and empirical findings. Cognition. 2014;132(3):342-382.

2. Cooperrider K, Nunez R. How We Make Sense of Time. Scientific American. 2016;27(6):38-43.

3. Bergen B, Chan Lau TT. Writing direction affects how people map space onto time. Frontiers in Psychology. 2012;3:109.

4. De Sousa H. Generational differences in the orientation of time in Cantonese speakers as a function of changes in the direction of Chinese writing. Frontiers in Psychology. 2012;3:255.

5. Beller S, Bender A, Bannardo G, editors. Spatial frames of reference for temporal relations: A conceptual analysis in English, German, and Tongan. Proceedings of the Annual Meeting of the Cognitive Science Society. 2005;27(27):220-225.

6. Bender A, Beller S. Cultural variation in numeration systems and their mapping onto the mental number line. Journal of Cross-Cultural Psychology. 2011;42(4):579-597.

7. Bender A, Rothe-Wulf A, Huther L, Beller S. Moving forward in space and time: how strong is the conceptual link between spatial and temporal frames of reference?. Frontiers in Psychology. 2012;3:486.

8. Evans V. The structure of time: Language, meaning and temporal cognition. Amsterdam:John Benjamins Publishing;2003.

9. Moore KE. Ego-based and field-based frames of reference in space to time metaphors. In M. Achard M, Kemmer S, editors. Language, culture, and mind. Stanford, CA:CSLI Publications;2004. pp.151-165.

10. Moore KE. Space-to-time mappings and temporal concepts. Cognitive Linguistics. 2006;17(2):199-244.

11. Moore KE. Ego-perspective and field-based frames of reference: Temporal meanings of FRONT in Japanese, Wolof, and Aymara. Journal of Pragmatics. 2011;43(3):759-776.

12. Nunez R, Cooperrider K. The tangle of space and time in human cognition. Trends in Cognitive Sciences. 2013;17(5):220-229.

13. Jamalian A, Tversky B. Gestures alter thinking about time.
Proceedings of the Annual Meeting of the Cognitive Science Society. 2012;34(34):503-508.

14. Le Guen O, Balam P, Ildefonsa L. No metaphorical timeline in gesture and cognition among Yucatec Mayas. Frontiers in Psychology. 2012;3:271.

15. Nunez RE, Sweetser E. With the future behind them: Convergent evidence from Aymara language and gesture in the crosslinguistic comparison of spatial construals of time. Cognitive Science. 2006;30(3):401-450.

16. Weger UW, Pratt J. Time flies like an arrow: Spacetime compatibility effects suggest the use of a mental timeline. Psychonomic Bulletin \& Review. 2008;15(2):426-430. 17. Kranjec A. Extending spatial frames of reference to temporal concepts. Proceedings of the Annual Meeting of the Cognitive Science Society. 2006;28(28):447-452.

18. Miles LK, Tan L, Noble GD, Lumsden J, Macrae CN. Can a mind have two time lines? Exploring space-time mapping in Mandarin and English speakers. Psychonomic Bulletin \& Review. 2011;18(3):598-604.

19. Walsh V. A theory of magnitude: Common cortical metrics of time, space and quantity. Trends in Cognitive Sciences. 2003;7(11):483-488.

20. Bennardo G, Beller S, Bender A. Temporal frames of reference: Conceptual analysis and empirical evidence from German, English, Mandarin Chinese and Tongan. Journal of Cognition and Culture. 2010;10(3-4):283-307.

21. Galton A. Time flies but space does not: Limits to the spatialisation of time. Journal of Pragmatics. 2011;43(3):695-703. 22. McGlone MS, Harding JL. Back (or forward?) to the future: The role of perspective in temporal language comprehension. Journal of Experimental Psychology: Learning, Memory, and Cognition. 1998;24(5):1211-1223.

23. Hong T, He X, Tillman R, Zhao X, Deng Y. The vertical and horizontal spatial-temporal conceptual metaphor representation of Chinese temporal words. Psychology. 2017;8(11):1679-1692. 24. Lakoff G, Johnson M. The metaphorical structure of the human conceptual system. Cognitive Science. 1980;4(2):195-208. 
25. Pederson E, Danziger E, Wilkins D, Levinson S, Kita S, Senft G. Semantic typology and spatial conceptualization. Language. 1998;74(3):557-589.

26. Senft G. Referring to space. Studies in Austronesian and Papuan languages. Oxford:Clarendon Press;1997.

27. Brown P. Time and space in Tzeltal: Is the future uphill?. Frontiers in Psychology. 2012;3:212.

28. Zinken J. Temporal frames of reference. In Filipovic L, Jaszczolt KM, editors. Language, cognition and space: The state of the art and new directions. London:Equinox Publishing Ltd;2010. pp. 479-498.

29. McTaggart JE. The unreality of time. Mind. 1908;17(68):457-474.

30. Shinohara K. Up-down orientation in time metaphors: Analysis of English and Japanese. Manuscript. Tokyo:Tokyo University of Agriculture and Technology;2000.

31. Tenbrink T. Space, time, and the use of language: An inves- tigation of relationships. Berlin:Walter de Gruyter;2008.

32. Evans V, Green M. An introduction to cognitive linguistics. New York:Routledge;2006.

33. Janda LA. Ten Lectures on cognitive linguistics as an empirical science. Leiden/Boston:Brill;2018.

34. Scott A. The vertical dimension and time in mandarin. Australian Journal of Linguistics. 1989;9(2):295-314.

35. Yu N. The contemporary theory of metaphor: A perspective from Chinese. Amsterdam/ Philadelphia:John Benjamins Publishing;1998.

36. Fuhrman O, McCormick K, Chen E, Jiang H, Shu D, Mao $\mathrm{S}$, et al. How linguistic and cultural forces shape conceptions of time: English and Mandarin time in 3D. Cognitive Science. 2011;35(7):1305-1328.

37. Kolesari J, Carlson L. How the physicality of space affects how we think about time. Memory \& Cognition. 2018;46(3):438-449. 